TINGKATKAN PENGGUNAAN MODEL QUANTUM TEACHING DAN

SNOWBALL THROWING DALAM PEMBELAJARAN IPS DAPAT

MENINGKATKAN BELAJAR SISWA KELAS III SD NEGERI NO.39

PASAR GOMPONG KEC.LENGAYANG SEMESTER I TAHUN

PELAJARAN 2016/2017

\author{
NURLAILI \\ Volume 1 Nomor 1 \\ JIPS ISSN: 2579-5449
}

\begin{abstract}
Activities and student learning outcomes Class III Elementary School No. 39 Market Gompong, District Lengayang district, South Coastal, in the school year 2016/2017 in learning about social studies teaching material Know the use of money according to need, less reach expectations, which are caused by the use of the learning model is less varied. To resolve the issue used collaborative learning model Quantum Teaching and Snowball Throwing. To test the effectiveness of the learning model in order to improve the activity and student learning outcomes, the procedures of classroom action research, which was conducted over two cycles.Each cycle taking the following four steps: (1) planning, (2) implementation, (3) observation, and (4) reflection. Through a variety of instruments and techniques of data collection, the result of research. To then be discussed by the techniques that have been set. Finally obtained a conclusion in order to address the subject matter of the study. The conclusions were as follows: (1) measures the use of collaborative models of Quantum Teaching and Snowball Throwing to increase the activity and student learning outcomes Class III Elementary

School No. 39 Market Gompong in learning about social studies teaching material to know the use of money as needed, including: (1) plan in accordance with the regulations, (2) carry out teaching in accordance with the plan,(3) evaluate the student's ability to meet any demands of learning, and (4) follow up on the results carefully. (2) Increased activity and student learning outcomes in social studies learning about teaching materials Getting to know the use of money in accordance with the requirements after use collaborative use of models Quantum Teaching and Snowball Throwing, occurs gradually. Improved student learning activities gradually are shown in several ways, such as participation, interest, and ability to make presentations. So even with improved learning outcomes, gradually able to shown students to meet any demands of learning. (3) The use of collaborative models of Quantum Teaching and Snowball Throwing in learning about social studies teaching material to know the use of money in accordance with the requirements shown to increase the activity and student learning outcomes Class III Elementary School No. 39 Market Gompong .
\end{abstract}

Keywords :activities and results learning, social learning, model of quantumteaching and snowball throwing 


\title{
TINGKATKAN PENGGUNAAN MODEL QUANTUM TEACHING DAN \\ SNOWBALL THROWING DALAM PEMBELAJARAN IPS DAPAT \\ MENINGKATKAN BELAJAR SISWA KELAS III SD NEGERI NO.39 \\ PASAR GOMPONG KEC.LENGAYANG SEMESTER I TAHUN \\ PELAJARAN 2016/2017
}

\begin{abstract}
ABSTRAK
Aktivitas dan hasil belajar siswa Kelas III SD Negeri No. 39 Pasar Gompong, Kecamatan Lengayang, Kabupaten Pesisir Selatan, Tahun Pelajaran 2016/2017 dalam pembelajaran IPS tentang materi ajar Mengenal penggunaan uang sesuai dengan kebutuhan, kurang mencapai harapan, yang disebabkan oleh penggunaan model pembelajaran kurang bervariatif. Untuk mengatasi masalah tersebut digunakan kolaborasi model pembelajaran Quantum Teaching dan Snowball Throwing. Untuk menguji efektivitas kedua model pembelajaran tersebut dalam rangka meningkatkan aktivitas dan hasil belajar siswa, menempuh prosedur penelitian tindakan kelas, yang dilaksanakan selama dua siklus. Setiap siklusnya menempuh empat tahapan berikut: (1) perencanaan, (2) pelaksanaan, (3) pengamatan, dan (4) refleksi. Melalui berbagai teknik dan instrumen pengumpul data, diperoleh hasil penelitian. Untuk kemudian dilakukan pembahasan berdasarkan teknik yang telah ditetapkan. Akhirnya diperoleh suatu simpulan guna menjawab pokok masalah penelitian. Simpulan dimaksud sebagai berikut : (1) Langkah-langkah penggunaan kolaborasi model Quantum Teaching dan Snowball Throwing untuk meningkatkan aktivitas dan hasil belajar

siswa Kelas III SD Negeri No. 39 Pasar Gompong dalam pembelajaran IPS tentang materi ajar mengenal penggunaan uang sesuai dengan kebutuhan, meliputi: (1) menyusun rencana sesuai dengan ketentuan, (2) melaksanakan KBM sesuai dengan rencana, (3) mengevaluasi kemampuan siswa dalam memenuhi setiap tuntutan pembelajaran, dan (4) menindaklanjuti hasilnya dengan cermat. (2) Peningkatan aktivitas dan hasil belajar siswa dalam pembelajaran IPS tentang materi ajar Mengenal penggunaan uang sesuai dengan kebutuhan setelah digunakan kolaborasi penggunaan model Quantum Teaching dan Snowball Throwing, terjadi secara bertahap. Peningkatan aktivitas belajar siswa secara bertahap tersebut ditunjukan dalam beberapa hal, seperti partisipasi, minat, dan kemampuan melakukan presentasi. Demikian pun dengan peningkatan hasil belajarnya, secara bertahap mampu ditunjukkan siswa dalam memenuhi setiap tuntutan pembelajaran. (3) Penggunaan kolaborasi model Quantum Teaching dan Snowball Throwing dalam pembelajaran IPS tentang materi ajar mengenal penggunaan uang sesuai dengan kebutuhan terbukti dapat meningkatkan aktivitas dan hasil belajar siswa Kelas III SD Negeri No. 39 Pasar Gompong.
\end{abstract}

Kata Kunci: aktivitas dan hasil belajar, pembelajaran ips, model quantum teaching dan snowball throwing

\section{PENDAHULUAN}

Latar belakang masalah, makna dan hakikat belajar diartikan sebagai proses membangun makna/pemahaman terhadap informasi dan/atau pengalaman. Proses membangun makna tersebut dapat dilakukan sendiri oleh siswa atau bersama orang lain. Proses itu disaring dengan persepsi, pikiran (pengetahuan awal), dan perasaan siswa (Indra Jati Sidi, 2004:4). Belajar bukanlah proses menyerap pengetahuan yang sudah jadi bentukan guru. Buktinya, hasil ulangan siswa berbedabeda padahal mendapat pengajaran yang sama, dari guru yang sama, dan pada saat yang sama.

Pembelajaran yang bermakna akan membawa siswa pada pengalaman belajar yang mengesankan. Pengalaman yang diperoleh siswa akan semakin berkesan apabila proses 


\section{Jurnal Ilmiah Pendidikan Scholastic}

pembelajaran yang diperolehnya merupakan hasil dari pemahaman dan penemuannya sendiri. Dalam konteks ini siswa mengalami dan melakukannya sendiri. Proses pembelajaran yang berlangsung melibatkan siswa sepenuhnya untuk merumuskan sendiri suatu konsep. Keterlibatan guru hanya sebagai fasilitator dan moderator dalam proses pembelajaran tersebut.

Merunut Kurikulum Berbasis

Kompetensi yang disempurnakan dalam Kurikulum Tingkat Satuan Pendidikan bahwa setiap individu mempunyai potensi yang harus dikembangkan, maka proses pembelajaran yang cocok adalah yang menggali potensi anak untuk selalu kreatif dan berkembang.

Namun kenyataan di lapangan belum menunjukkan ke arah pembelajaran yang bermakna. Para pendidik masih perlu penyesuaian dengan KTSP, para guru sendiri belum siap dengan kondisi yang sedemikian plural sehingga untuk mendesain pembelajaran yang bermakna masih kesulitan. Sistem pembelajaran duduk tenang, mendengarkan informasi dari guru sepertinya sudah membudaya sejak dulu, sehingga untuk mengadakan perubahan ke arah pembelajaran yang aktif, kreatif, menyenangkan agak sulit.

Berdasarkan pengamatan awal terhadap proses pembelajaran IPS di SD Negeri No. 39 Pasar Gompong diperoleh informasi bahwa selama proses pembelajaran, guru belum memberdayakan seluruh potensi dirinya sehingga sebagian besar siswa belum mampu mencapai kompetensi individual yang diperlukan untuk mengikuti pelajaran lanjutan. Beberapa siswa belum belajar sampai pada tingkat pemahaman. Siswa baru mampu menghafal fakta, konsep, prinsip, hukum, teori, dan gagasan inovatif lainnya pada tingkat ingatan, mereka belum dapat menggunakan dan menerapkannya secara efektif dalam pemecahan masalah sehari-hari yang kontekstual.

Pembelajaran Ilmu Pengetahuan Sosial (IPS) juga tidak luput dari kecenderungan proses pembelajaran teacher centered. Kondisi demikian tentu membuat proses pembelajaran hanya dikuasai guru. Apalagi pembelajaran IPS merupakan mata pelajaran sarat materi sehingga siswa dituntut memiliki pemahaman yang holistik terhadap materi yang disampaikan guru.

Upaya untuk membangkitkan motivasi siswa Kelas III SD Negeri No. 39 Pasar Gompong dalam pembelajaran IPS sudah dilakukan guru kelas dengan berbagai macam cara, seperti memberi kesempatan siswa untuk bertanya dan mengemukakan gagasan, serta mendesain pembelajaran dalam bentuk diskusi kelompok. Namun demikian, hasil pembelajaran IPS pada Ulangan Harian Semester I Tahun Pelajaran 2016/2017 belum begitu memuaskan. Hal tersebut dapat dilihat dari rata-rata nilai IPS yang hanya 71,29 berada pada urutan ke-4 setelah Bahasa Indonesia (rata-rata 79,22), Ilmu Pengetahuan Alam (rata-rata 76,35), dan Matematika (rata-rata 74,12).

Terkait belum optimalnya hasil belajar IPS siswa Kelas III SD Negeri No. 39 Pasar Gompong maka penulis berupaya untuk menerapkan model pembelajaran Quantum Teaching dan Snowball Throwing secara kolaborasi sebagai salah satu alternatif pembelajaran bermakna yang bermuara pada pembelajaran yang aktif, kreatif, efektif, dan menyenangkan.

Berdasarkan kondisi tersebut maka penulis tergerak untuk melakukan penelitian tindakan kelas yang berfokus pada masalah seperti telah diuraikan di atas, yakni penggunaan kolaborasi model Quantum Teaching dan Snowball Throwinguntuk meningkatkan aktivitas dan hasil belajar siswa Kelas III SD Negeri No. 39 Pasar Gompong pada mata pelajaran IPS tentang materi ajar Mengenal penggunaan uang sesuai dengan kebutuhan.

Berdasarkan latar belakang masalah di atas, dapat dirumuskan tiga pokok masalah yaitu : 1) Bagaimana langkah-langkah menggunakan kolaborasi model Quantum Teaching dan Snowball Throwing untuk meningkatkan hasil belajar IPS tentang materi mengenal penggunaan uang sesuai dengan kebutuhanpada siswa Kelas III SD Negeri No. 39 Pasar Gompong? 2) Bagaimana peningkatan hasil belajar siswa Kelas III SD Negeri No. 39 Pasar Gompong dalam pembelajaran IPS tentang materi Mengenal penggunaan uang sesuai dengan kebutuhan setelah digunakan kolaborasi model Quantum Teaching dan Snowball Throwing? 3) Apakah penggunaan kolaborasi model Quantum Teaching dan Snowball Throwingdapat meningkatkan hasil belajar siswa Kelas III SD Negeri No. 39 Pasar Gompong dalam pembelajaran IPS tentang materi Mengenal penggunaan uang sesuai dengan kebutuhan?

Penelitian tindakan kelas ini bertujuan untuk 1) Mendeskripsikan langkah-langkah menggunakan kolaborasi model Quantum Teaching dan Snowball Throwing untuk meningkatkan hasil belajar IPS tentang materi mengenal penggunaan uang sesuai dengan 


\section{Jurnal Ilmiah Pendidikan Scholastic}

kebutuhanpada siswa Kelas III SD Negeri No. 39 Pasar Gompong. 2) Mendeskripsikan peningkatan hasil belajar siswa Kelas III SD Negeri No. 39 Pasar Gompong dalam pembelajaran IPS tentang materi Mengenal penggunaan uang sesuai dengan kebutuhan setelah digunakan kolaborasi model Quantum
Teaching dan Snowball Throwing.

Mendeskripsikan penggunaan kolaborasi model Quantum Teaching dan Snowball Throwingdapat meningkatkan hasil belajar siswa Kelas III SD Negeri No. 39 Pasar Gompong dalam pembelajaran IPS tentang materi Mengenal penggunaan uang sesuai dengan kebutuhan.

\section{METODOLOGI PENELITIAN}

Yang menjadi subjek penelitianadalah siswa Kelas III SD Negeri No. 39 Pasar Gompong, Kecamatan Lengayang, Kabupaten Pesisir Selatan, Tahun Pelajaran 2016/2017, yang berjumlah 38 orang yang sedang menempuh semester 2 dalam pembelajaran mata pelajaran IPs.

Setting dalam penelitian ini meliputi: tempat dan waktu penelitian, serta siklus PTK. Lebih jelasnya mengenai hal itu, sebagai berikut

1) Penelitian tindakan kelas ini dilaksanakan di Kelas III SD Negeri No. 39 Pasar Gompong, Kecamatan Lengayang, Kabupaten Pesisir Selatan, Tahun Pelajaran 2016/2017.2) Pemilihan sekolah ini bertujuan untuk memperbaiki dan meningkatkan pengelolaan proses pembelajaran mata pelajaran IPS tentang materi mengenal penggunaan uang sesuai dengan kebutuhan.

Penelitian ini akan dilaksanakan pada semester II tahun pelajaran 2016/2017. Penentuan waktu penelitian mengacu pada kalender akademik sekolah, karena PTK memerlukan beberapa siklus yang membutuhkan proses belajar mengajar efektif di kelas.

PTK ini dilaksanakan melalui dua siklus untuk melihat peningkatan hasil belajar siswa Kelas III SD Negeri No. 39 Pasar Gompong dalam pembelajaran IPS tentang materi ajar mengenal penggunaan uang sesuai dengan kebutuhan melalui penggunaan kolaborasi model Quantum Teaching dan Snowball Throwing.

Sumber data penelitian ini adalah siswa, guru, teman sejawat dan kolabolator. Lebih jelasnya, sebagai berikut :

Untuk mendapatkan data tentang hasil belajar siswa Kelas III SD Negeri No. 39 Pasar Gompong dalam pembelajaran IPS tentang materi mengenal penggunaan uang sesuai dengan kebutuhan setelah digunakan kolaborasi model Quantum Teaching dan Snowball Throwing.

Untuk melihat keberhasilan tingkat implementasi pembelajaran IPS tentang materi mengenal penggunaan uang sesuai dengan kebutuhan dengan menggunakan kolaborasi model Quantum Teaching dan Snowball Throwing untuk meningkatkan hasil belajar siswa Kelas III SD Negeri No. 39 Pasar Gompong.

Teman sejawat dan kolabolator dimaksudkan sebagai sumber data untuk melihat implementasi PTK secara komprehensif, baik dari sisi siswa maupun guru.

Teknik pengumpulan data penelitian ini adalah tes, observasi, wawancara, dan diskusi. 1) Tes dipergunakan untuk mendapatkan data tentang hasil belajar siswa. 2) Observasi dipergunakan untuk mengumpulkan data tentang aktivitas belajar siswa dalam pembelajaran IPS tentang materi mengenal penggunaan uang sesuai dengan kebutuhan dengan menggunakan kolaborasi model Quantum Teaching dan Snowball Throwing. 3) Wawancara dipergunakan untuk mendapatkan data tentang tingkat keberhasilan implementasi pembelajaran IPS tentang materi mengenal penggunaan uang sesuai dengan kebutuhan dengan menggunakan kolaborasi model Quantum Teaching dan Snowball Throwingdalam meningkatkan hasil belajar siswa Kelas III SD Negeri No. 39 Pasar Gompong. 4) Diskusi antara guru, teman sejawat, dan kolabolator untuk merefleksi hasil siklus PTK.

Data yang dikumpulkan pada setiap kegiatan observasi dari pelaksanaan siklus PTK dianalisis secara deskriptif dengan menggunakan teknik persentase untuk melihat kecenderungan yang terjadi dalam kegiatan pembelajaran. 1). Hasil belajar: dengan menganalisis nilai rata-rata hasil evaluasi pada setiap siklus. Kemudian dikategorikan dalam klasifikasi tinggi, sedang, dan rendah. 2) Aktivitas siswa dalam PBM: dengan menganalisis tingkat keaktifan siswa dalam PBM. Kemudian dikategorikan dalam klasifikasi tinggi, sedang, dan rendah. 3) Implementasi pembelajaran IPS tentang materi mengenal penggunaan uang sesuai dengan kebutuhan dengan menggunakan kolaborasi model Quantum Teaching dan Snowball Throwing, dengan cara menganalisis tingkat 


\section{Jurnal Ilmiah Pendidikan Scholastic}

keberhasilan, kemudian dikategorikan dalam klasifikasi berhasil, kurang berhasil, dan tidak berhasil.

Alur penelitian ini menempuh prosedur penelitian tindakan kelas, yang berupa siklus perbaikan pembelajaran yang dilakukan secara kolaborasi antara guru pelaksana tindakan, teman sejawat dan kolabolator, serta siswa. Dalam setiap siklusnya, terdapat empat tahapan, antara lain: (1) perencanaan, (2) pelaksanaan, (3) pengamatan, dan (4) refleksi.

\section{HASIL PENELITIAN DAN PEMBAHASAN}

Pelaksanaan kegiatan belajar mengajar IPS tentang mengenal penggunaan uang sesuai dengan kebutuhan yang disajikan dengan menggunakan kolaborasi model model pembelajaran Quantum Teaching dan Snowball Throwingpada siklus I, cukup memberi dampak yang terhadap aktivitas dan hasil belajar siswaKelas III SD Negeri No. 39 Pasar Gompong. Meski demikian, pengamat menilai dan mencatat beberapa hal, seperti berikut : 1) Aktivitas guru dan siswa pada tahap kegiatan awal, tampak ada kesan kaku. Hal ini disebabkan oleh karena mereka belum terbiasa dalam memulai kegiatan pembelajaran seperti itu. 2) Motivasi yang diberikan guru, cukup menyentuh perasaan siswa. Hal ini tampak dari semangat siswa untuk mengikuti proses pembelajaran. 3) Sebagian besar waktu pada kegiatan inti, lebih banyak digunakan guru untuk membimbing dan mengarahkan siswa agar berlaku sebagaimana yang diharapkan. 4) Sebagian besar siswa kurang aktif dalam setiap tahapan belajar. Hal ini karena mereka belum terbiasa dengan kondisi yang diinginkan. 5) Peran fasilitator dan mediator masih kurang dilakukan secara profesional oleh guru. Hal ini disebabkan oleh kurangnya penguasaan guru terhadap tugasnya ini dalam kondisi pembelajaran yang diinginkan pada kedua model pembelajaran yang dikolaborasikan untuk meningkatkan aktivitas dan hasil belajar siswa.

Selain itu, hasil belajar siswa pada siklus I pun mengalami peningkatan. Hal ini dapat terjadi karena adanya perubahan pada aktivitas belajar siswa. Berdasarkan evaluasi siklus I, diperoleh nilai hasil belajar siswa.

Pada tabel di atas, diketahui keseluruhan siswa memperoleh nilai hasil belajar lebih dari kriteria ketuntasan minimal (KKM) yang telah ditetapkan, yaitu nilai 55 .

Untuk mengetahui keberhasilan pembelajaran siklus I, telah dilakukan refleksi terhadap kinerja guru dan siswa, yang dilakukan secara kolaborasi antara guru pelaksana tindakan dan pengamat. Adapun hasilnya, sebagai berikut : 1) Kemampuan guru dalam mengelola proses pembelajaran IPS tentang materi ajar mengenal penggunaan uang sesuai dengan kebutuhan yang disajikan dengan menggunakan kolaborasi model Quantum Teaching dan Snowball Throwingpada siklus I, dinilai cukup baik. Bahkan lebih baik dari sebelumnya. 2) Aktivitas belajar siswa dalam mengikuti setiap tahapan pembelajaran IPS tentang materi ajar mengenal penggunaan uang sesuai dengan kebutuhan yang disajikan dengan menggunakan kolaborasi model Quantum Teaching dan Snowball Throwing pada siklus I, sedikit banyaknya sudah mengalami perubahan ke arah yang lebih baik dari sebelumnya. Meski belum sebaik yang diharapkan, hal ini dapat dimaklumi karena mereka kurang terbiasa mengikuti proses belajar seperti ini. Dari 27 orang siswa, yang sebelumnya diketahui ada 20 orang yang tidak partisipasi, tidak berminat, tidak perhatian, dan tidak bermotivasi meningkat menjadi kurang partisipasi, kurang berminat, kurang perhatian, dan kurang mampu presentasi. Sementara itu, 7 orang siswa lainnya yang sebelumnya diketahui kurang partisipasi, kurang berminat, kurang perhatian, dan kurang bermotivasi menjadi cukup partisipasi, cukup berminat, cukup perhatian, dan cukup mampu presentasi. 3) Dari 27 orang siswa baru diketahui ada 20 orang $(63,15 \%)$ yang dinyatakan cukup mampu memenuhi setiap tuntutan pembelajaran IPS tentang materi ajar mengenal penggunaan uang sesuai dengan kebutuhan yang disajikan dengan menggunakan kolaborasi model Quantum Teaching dan Snowball Throwing. Sementara itu, selebihnya dari mereka, yakni 7 orang siswa $(36,85 \%)$ dinyatakan kurang mampu memenuhi tuntutan tersebut. 4) Belum tercapainya target kinerja yang diharapkan, baik oleh guru maupun siswa lebih disebabkan karena masing-masing belum terbiasa dengan langkah-langkah kegiatan belajar mengajar berdasarkan tuntutan kolaborasi model Quantum Teaching dan Snowball Throwing. Itu sebabnya, masih ada beberapa orang siswa yang dinilai kurang mampu memenuhi setiap tuntutan pembelajaran. Untuk mengatasi masalah tersebut, maka pada PTK siklus II, akan 


\section{Jurnal Ilmiah Pendidikan Scholastic}

diupayakan hal-hal berikut : 1) Persiapan guru harus ditingkatkan, terutama dalam memahami langkah-langkah pengelolaan proses pembelajaran IPS tentang materi ajar mengenal penggunaan uang sesuai dengan kebutuhan yang disajikan dengan menggunakan kolaborasi model Quantum Teaching dan Snowball Throwing. 2) Guru harus mampu mempertahankan dan meningkatkan hal-hal yang sudah cukup baik dalam mengelola proses pembelajaran siklus I. Guru harus mampu meningkatkan partisipasi, minat, perhatian, dan kemampuan siswa dalam presentasi. Hal-hal yang dianjurkan untuk itu, di antaranya mengaktifkan siswa melalui tanya jawab, pemberian tugas secara kelompok, pemberian penghargaan dan sanksi kepada siswa yang layak untuk mendapatkannya. 3) Kinerja siswa meski meningkat, tetapi belum mencapai harapan, baik dilihat dari partisipasi, perhatian, minat, dan kemampuan presentasi. Hal ini lebih disebabkan oleh karena siswa belum terbiasa dengan langkah-langkah belajar berdasarkan tuntutan kolaborasi model pembelajaran Quantum Teaching dan Snowball Throwing. Atas dasar itu, kepada siswa disarankan agar siklus II mulai membiasakan diri dengan langkah-langkah belajar yang diinginkan, dengan mengikuti secara sungguh-sungguh tentang apa yang dianjurkan oleh guru. Selain itu, siswa pun harus: (1) miliki persiapan fisik dan mental, agar dapat berkonsentrasi pada langkah-langkah belajar yang akan dijelaskan guru; (2) bertanya kepada guru apabila ada di antara langkahlangkah belajar yang kurang dan atau belum dipahami dengan baik; (3) belajar secara sungguh-sungguh, yang ditunjukkan dengan cara berpartisipasi secara aktif, pusatkan perhatian pada apa yang sedang dipelajari, minat dan motivasi belajar terus tingkatkan dengan cara fokus pada tujuan yang ingin dicapai setelah mengikuti proses pembelajaran; (4) selain itu, berusaha untuk mencapai penghargaan yang akan diberikan guru, dan takutlah dengan sanksi yang akan diberikannya apabila kurang baik dalam proses dan hasil belajar; (5) saling belajar dengan baik, karena masing-masing memiliki kelebihan yang sangat diperlukan oleh yang lain; (6) berjiwa lapanglah dalam memberi dan menerima masukan yang ditujukan untuk kebaikan.

Pelaksanaan pembelajaran IPS tentang materi ajar Mengenal penggunaan uang sesuai dengan kebutuhan yang disajikan dengan menggunakan kolaborasi model Quantum Teaching dan Snowball Throwingdidasarkan pada hasil refleksi siklus I. Ketentuan ini dapat diikuti dengan baik oleh guru maupun siswa. Pada siklus II ini tidak lagi terlihat adanya siswa yang tinggal diam tidak turut ambil bagian dalam pembelajaran. Banyak siswa yang sebelumnya enggan untuk bertanya sehubungan dengan kekurangpahamannya terhadap materi yang dipelajari, hal ini tidak lagi terjadi. Adanya perubahan aktivitas belajar siswa pada siklus II ini tidak terlepas dari upaya yang dilakukan guru. Hal ini dapat diketahui dari catatan dan hasil penilaian pengamat, seperti rincian berikut : (1) Aktivitas guru dan siswa pada tahap kegiatan awal, mulai terbiasa dengan langkah-langkah prapembelajaran IPS tentang materi ajar Mengenal penggunaan uang sesuai dengan kebutuhan yang disajikan dengan menggunakan kolaborasi model Quantum Teaching dan Snowball Throwing. Guru dan siswa sudah tidak merasa kaku lagi, sehingga kegiatan awal dapat berlangsung cukup baik dari sebelumnya (kegiatan awal pada PTK siklus 1). Guru cukup berhasil memotivasi siswa, dengan cara akan memberikan penghargaan (reward) bagi siapa saja di antara siswanya yang berhasil mencapai hasil belajar lebih baik, dan kepada siswa yang kurang berhasil akan diberikan sanksi berupa pemberian tugas individu yang akan ditentukan nanti setelah proses pembelajaran siklus II berlangsung. Melalui upaya tersebut, ada perubahan pada sikap siswa yang ditunjukkan oleh partisipasi, perhatian, minat, dan kemampuan melakukan presentasi pada tahap pratindakan. 2) Pada kegiatan inti siklus II, peran guru dan siswa sudah cukup mengenai sasaran. Guru tidak lagi menghabiskan waktu untuk menyajikan materi, melainkan lebih banyak membimbing dan mengarahkan siswa pada proses belajar yang sebenarnya dalam memenuhi tuntutan pembelajaran. Demikian pun dengan proses belajar siswa, tampak lebih baik dari sebelumnya, yang ditunjukkan oleh partisipasi masing-masing, perhatian terhadap penjelasan guru dan tugas, minat dan kemampuan melakukan presentasi. Tidak diketahui lagi adanya siswa yang kurang bersungguh-sungguh dalam mengikuti proses pembelajaran. Dari yang sebelumnya segan untuk bertanya kepada guru, pada siklus II sudah mulai banyak siswa yang berani bertanya kepada guru, terutama tentang cara-cara memenuhi tuntutan pembelajaran. 3) Terhadap siswa yang mengalami kesulitan dalam memenuhi setiap tuntutan pembelajaran, guru memberikan jalan keluar dengan cara memahamkan siswa pada tuntutan tersebut. Sebelum siswa dapat keluar dari kesulitannya, 


\section{Jurnal Ilmiah Pendidikan Scholastic}

guru belum beranjak dari tempat duduk siswa yang bersangkutan. Tindakan ini, disambut dengan baik oleh siswa, dan karena itu pula yang bersangkutan dapat belajar lebih baik dalam suasana yang menyenangkan. 4) Guru sudah mampu menebar pandangan kepada seluruh siswa, yang ditunjukkan oleh perhatiannya pada siapa saja yang menghadapi kesulitan dalam memenuhi tuntutan pembelajaran, maka segeralah ia membantu mencarikan jalan keluarnya hingga lepas dari kesulitan tersebut. 5) Saat siswa sedang memenuhi tuntutan pembelajaran, guru berusaha memfasilitasi apa yang dibutuhkan siswa. Oleh karena itu, proses belajar siswa tampak lebih menyenangkan daripada sebelumnya.

Melengkapi catatan hasil pengamatan di atas, pada tabel berikut ini disertakan penilaian pengamat terhadap kemampuan guru dalam mengelola proses IPS tentang materi ajar Mengenal penggunaan uang sesuai dengan kebutuhan yang disajikan dengan menggunakan kolaborasi model Quantum Teaching dan Snowball Throwing.

Bukan saja guru yang dinilai kemampuannya, tetapi juga siswa dalam mengikuti jalannya proses pembelajaran IPS tentang materi ajar Mengenal penggunaan uang sesuai dengan kebutuhan yang disajikan dengan menggunakan kolaborasi model Quantum Teaching dan Snowball Throwing, baik dilihat dari minat, perhatian, partisipasi, maupun kemampuan melakukan presentasi, seperti tertuang pada tabel berikut :

Selain itu, melalui evaluasi pembelajaran siklus II dapat diketahui nilai kemampuan untuk masing-masing siswa. Dari 27 orang siswa diketahui ada 24 orang $(91,17 \%)$ yang dinyatakan mampu memenuhi tuntutan pembelajaran IPS tentang materi ajar mengenal penggunaan uang sesuai dengan kebutuhan yang disajikan dengan menggunakan kolaborasi model Quantum Teaching dan Snowball Throwing. Sementara itu selebihnya dari mereka, yakni 3 orang siswa $(8,03 \%)$ dinyatakan masih cukup mampu. Adanya nilai yang diperoleh masingmasing siswa pada siklus II, tampak seperti pada tabel berikut :

Berdasarkan hasil refleksi siklus II, dapat diketahui keberhasilan dan kegagalan IPS tentang materi ajar Mengenal penggunaan uang sesuai dengan kebutuhan yang disajikan dengan menggunakan kolaborasi model Quantum Teaching dan Snowball Throwingdi siklus II.Adapun hasilnya, sebagai berikut
Kemampuan guru dalam mengelola proses IPS tentang materi ajar Mengenal penggunaan uang sesuai dengan kebutuhan yang disajikan dengan menggunakan kolaborasi model Quantum Teaching dan Snowball Throwingpada siklus II, diketahui lebih baik dari siklus sebelumnya. Peningkatan kemampuan guru tersebut ditunjukkan oleh kemampuannya dalam menyusun rencana pelaksanaan pembelajaran, melaksanakan pembelajaran, dan mengevaluasi serta menindaklanjuti hasilnya. Berdasarkan hasil penilaian pengamat, diperoleh rata-rata nilai cukup mampu untuk masing-masing tahap dalam proses pembelajaran tersebut. (2) Aktivitas belajar siswa dalam mengikuti proses IPS tentang materi ajar Mengenal penggunaan uang sesuai dengan kebutuhan yang disajikan dengan menggunakan kolaborasi model Quantum Teaching dan Snowball Throwingpada siklus II, diketahui lebih baik dari siklus sebelumnya. Hal ini diketahui dari partisipasi, minat, perhatian, dan kemampuan melakukan presentasi pada masing-masing siswa yang sebelumnya (pada siklus I) banyak yang kurang partisipasi, kurang berminat, kurang perhatian, dan kurang mampu presentasi setelah mengikuti proses pembelajaran IPS tentang materi ajar Mengenal penggunaan uang sesuai dengan kebutuhan yang disajikan dengan menggunakan kolaborasi model Quantum Teaching dan Snowball Throwingsiklus II meningkat pada kategori ketiga dan keempat. Dari 27 orang siswa, diketahui ada 25 orang $(81,57 \%)$ yang sebelumnya kurang partisipasi, kurang berminat, kurang perhatian, dan kurang mampu presentasi meningkat menjadi cukup partisipasi, cukup berminat, cukup perhatian, dan cukup bermotivasi. Sementara itu, 7 orang siswa $(18,43 \%)$ lainnya yang sebelumnya diketahui cukup partisipasi, cukup berminat, cukup perhatian, dan cukup mampu presentasi menjadi mampu berpartisipasi, minatnya lebih tinggi, mampu memperhatikan, dan lebih mampu presentasi. Perubahan tersebut didasarkan pada hasil penilaian pengamat. (3) Dari 27 orang siswa diketahui secara keseluruhan dinyatakan tuntas. (4) Cukup tercapainya target kinerja yang diharapkan, baik oleh guru maupun siswa lebih disebabkan karena masing-masing sudah terbiasa dengan langkah-langkah belajar mengajar IPS tentang materi ajar Mengenal penggunaan uang sesuai dengan kebutuhan berdasarkan langkahlangkah kolaborasi model Quantum Teaching dan Snowball Throwing.

Setelah melakukan penelitian dan 


\section{Jurnal Ilmiah Pendidikan Scholastic}

menganalisis hasilnya, terbuktilah bahwa penggunaan kolaborasi model Quantum Teaching dan Snowball Throwingdalam pembelajaran IPS tentang materi ajar Mengenal penggunaan uang sesuai dengan kebutuhandapat meningkatkan aktivitas dan hasil belajar siswa. Peningkatan aktivitas dan hasil belajar siswa tidak saja terjadi pada siklus II tetapi pada siklus I pun seluruh siswa mengalami peningkatan ke arah yang lebih baik dari sebelumnya.

Meningkatnya aktivitas belajar siswa pada siklus I ditandai oleh partisipasi, perhatian, minat, dan kemampuan melakukan presentasi. Itu sebabnya, hasil belajar masing-masing siswa pada siklus I mencapai kriteria ketuntasan minimal. Namun, hasil tersebut masih dianggap kurang memuaskan bagi guru dan juga siswa. Atas dasar itu, maka dilaksanakan kembali siklus II. Adanya peningkatan aktivitas dan hasil belajar siswa dalam pembelajaran siklus I, tidak terlepas dari meningkatnya eksistensi kemampuan guru dalam mengelola proses pembelajaran IPS tentang materi ajar Mengenal penggunaan uang sesuai dengan kebutuhan yang disajikan dengan menggunakan kolaborasi model Quantum Teaching dan Snowball Throwing.

\section{KESIMPULAN}

Setelah melakukan serangkaian kegiatan hingga diperoleh data dan kemudian dibahas, akhirnya dapat diambil suatu simpulan untuk menjawab setiap pokok masalah yang diajukan dalam penelitian ini. Simpulan dimaksud, sebagai berikut : (1) Langkah-langkah penggunaan kolaborasi model Quantum Teaching dan Snowball Throwinguntuk meningkatkan aktivitas dan hasil belajar siswa Kelas III SD Negeri No. 39 Pasar Gompong dalam pembelajaran IPS tentang materi ajar mengenal penggunaan uang sesuai dengan kebutuhan, meliputi: (1) menyusun rencana sesuai dengan ketentuan, (2) melaksanakan KBM sesuai dengan rencana, (3) mengevaluasi kemampuan siswa dalam memenuhi setiap tuntutan pembelajaran, dan (4) menindaklanjuti hasilnya dengan cermat. (2) Peningkatan aktivitas dan hasil belajar siswa dalam
Peningkatan aktivitas dan hasil belajar siswa kembali terjadi pada proses pembelajaran IPS tentang materi ajar Mengenal penggunaan uang sesuai dengan kebutuhan yang disajikan dengan menggunakan kolaborasi model Quantum Teaching dan Snowball Throwingsiklus II. Partisipasi, perhatian, minat, dan kemampuan siswa dalam melakukan presentasi pada siklus II ini, jauh lebih baik daripada siklus I. Sehingga hasil belajarnya pun turut meningkat lebih baik. Bahkan keseluruhan siswa perolehan nilainya melebihi nilai kriteria ketuntasan minimal yang telah ditetapkan. Hal ini pun tidak terjadi dengan sendirinya, melainkan hasil usaha guru.

$$
\text { Dengan demikian, penggunaan }
$$

kolaborasi model Quantum Teaching dan Snowball Throwing dalam pembelajaran IPS tentang materi ajar Mengenal penggunaan uang sesuai dengan kebutuhanuntuk meningkatkan aktivitas dan hasil belajar siswa Kelas III SD Negeri No. 39 Pasar Gompong, Kecamatan Lengayang, Kabupaten Pesisir Selatan, dinyatakan berakhir pada siklus II. Hal ini karena baik guru maupun siswa sudah merasa puas dengan peningkatan yang terjadi pada siklus II.

pembelajaran IPS tentang materi ajar Mengenal penggunaan uang sesuai dengan kebutuhan setelah digunakan kolaborasi penggunaan model Quantum Teaching dan Snowball Throwing, terjadi secara bertahap. Peningkatan aktivitas belajar siswa secara bertahap tersebut ditunjukan dalam beberapa hal, seperti partisipasi, minat, dan kemampuan melakukan presentasi. Demikian pun dengan peningkatan hasil belajarnya, secara bertahap mampu ditunjukkan siswa dalam memenuhi setiap tuntutan pembelajaran. (3) Penggunaan kolaborasi model Quantum Teaching dan Snowball Throwing dalam pembelajaran IPS tentang materi ajar Mengenal penggunaan uang sesuai dengan kebutuhan terbukti dapat meningkatkan aktivitas dan hasil belajar siswa Kelas III SD Negeri No. 39 Pasar Gompong. 


\section{DAFTAR PUSTAKA}

Bobbi DePorter. 2002. Quantum Teaching. Boston: Allyn Bacon.

Suryosubroto. 1997. Proses Belajar Mengajar di Sekolah. Jakarta: Rineka Cipta.

Depdiknas. 2001. Buku 1 Manajemen Peningkatan Mutu Pendidikan Berbasis Sekolah. Jakarta: Depdiknas.

... 2002. Petunjuk Pelaksanaan Penilaian Kelas di SD, SDLB, SLB Tingkat Dasar, dan MI. Jakarta: Depdiknas.

.....2006. Standar Kompetensi Mata Pelajaran Pengetahuan Sosial Kurikulum Berbasis Kompetensi. Jakarta : Puskur Balitbang Depdiknas.

Indra Jati Sidi. 2004. Pelayanan Profesional, Kegiatan Belajar-Mengajar yang Efektif. Jakarta: Puskur Balitbang Depdiknas.

Nana Sudjana. 2002. Penilaian Hasil Proses Belajar Mengajar. Bandung: Remaja Rosdakarya.

Purwadi Suhandini. 2000. Penelitian Tindakan Kelas. Semarang: Lemlit UNNES.

Puskur Balitbang Depdiknas. 2003. Model- model Pembelajaran Efektif. (www.puskur_balitbang_depdiknas.com ).upadate 28 Agustus 2007.

Supardi, Suharsimi Arikunto, Suhardjono. 2006. Penelitian Tindakan Kelas. Yakarta: Bumi Aksara.

Tim MKDK IKIP Semarang. 1990. Psikologi Belajar. Semarang: IKIP Semarang Press.

Tintin Heryatin. 2004. Pengembangan Model Pembelajaran Quantum dalam Mata Pelajaran IPS

dalam Rangka Pengembangan Kurikulum Berbasis Sekolah. Hasil Penelitian. (http://pps.upi.edu/org/ abstrakthesis/abstrakpk/abstrakpk04.htm 1). update 28 Agustus 2007.

Zainal Aqib. 2007. Penelitian Tindakan Kelas untuk Guru. Bandung: Yrama Widya.

Peningkatan Hasil Belajar Siswa Kelas III SD Negeri 39 Pasar Gompong dalam Pembelajaran IPS Melalui Penggunaan Model Quantum Teaching dan Snowball Throwing 